Copyright $\odot 2005$ SAGE Publications (London, Thousand Oaks, CA and New Delhi) 1468-7968

Vol 5(1): 9-29;049922

DOI:10.1177/1468796805049922

www.sagepublications.com

\title{
Spanish nationalism
}

\section{Ethnic or civic?}

\section{DIEGO MURO}

King's College London

\section{ALEJANDRO QUIROGA}

London School of Economics

\begin{abstract}
In recent years, it has been a common complaint among scholars to acknowledge the lack of research on Spanish nationalism. This article addresses the gap by giving an historical overview of 'ethnic' and 'civic' Spanish nationalist discourses during the last two centuries. It is argued here that Spanish nationalism is not a unified ideology but it has, at least, two varieties. During the 19th-century, both a 'liberal' and a 'conservative-traditionalist' nationalist discourse were formulated and these competed against each other for hegemony within the Spanish market of ideas. In the 20th-century, these two discourses continued to be present and became backbones of different political regimes. However, after the emergence of the Basque and Catalan nationalist movements, Spanish nationalists unified as a counter-force to these regional sources of identity. In fact, one can see 20th-century Spanish nationalism as a dialectical struggle between the centre and the periphery.
\end{abstract}

KEYWORDS Basque Country $\bullet$ Catalonia $\bullet$ nation $\bullet$ patriotism $\bullet$ regionalism - Spain

Spanish political life is often marked by an exchange of attacks between Spanish and regional nationalisms. While the existence of peripheral nationalisms is widely acknowledged, Spanish nationalism is constantly ignored by the political spectrum. This is often the case for most state nationalisms but it is remarkable in the case of Spanish nationalism. In Spain, the amount of research devoted to the study of peripheral 
nationalisms dwarfs that dedicated to Spanish nationalism. It was not until two renowned historians, Juan Pablo Fusi and Borja de Riquer, presented their opposing views in the pages of the journal Historia Social in the early 1990s that Spanish nationalism became a recurrent subject of academic enquiry. ${ }^{2}$ Even though both historians agreed on the weakness of the Spanish state building process in the 19th-century, they differed on the level of resonance of Spanish nationalism vis-à-vis peripheral nationalisms. Further analyses of Spanish nationalism have challenged the idea of the precarious nationalization of the masses by the state and presented the persistence of regionalism as compatible with the creation of a Spanish national identity (Archilés \& Martí, 2001; Segarra, 2001). All these studies have approached the topic from an 'instrumentalist' perspective, depicting Spanish nationalism primarily as an instrument of socioeconomic development or state building. These explanations offer a good insight into the aims of political elites and the manipulative capacity of nationalist ideology, but they usually say little about nationalist rhetoric and its powerful appeal to the population.

The present work aims to advance a different line of enquiry that focuses not so much on the state-building process, but on nationalist discourse and the top-down and bottom-up 'construction' of the nation as an imagined community. As exemplified in Anderson's Imagined Communities, the 'constructivist' approach stresses the creative and changing character of national identity, together with its adaptability to diverse political contexts in time and space. In our case study, the changing nature of Spanish nationalism is understood in terms of a process of historical transformation, in which different conceptions of the nation were elaborated in diverse political contexts throughout the 19th-and 20th-centuries. By exploring the civic and ethnic elements that define the Spanish nation in the nationalist discourse, it is possible to analyse the changing character of national identity and differentiate between assorted traditions in Spanish nationalism.

\section{ETHNIC AND CIVIC NATIONALISM}

Before turning to the character of Spanish nationalism, this article briefly explores the meaning of the terms 'ethnic' and 'civic' in the literature on nationalism. The first contemporary scholars to distinguish between two kinds of nationalisms were the historians Friedrich Meinecke (1970[1907]), Hans Kohn (1944) and John Plamenatz (1976). From a German perspective, Meinecke differentiated between 'cultural nations' based on 'some jointly experienced cultural heritage', and 'political nations' based on the 'unifying force of a common political history and constitution' (Meinecke, 
1970[1907]). Kohn and Plamenatz used different concepts of nationhood with respect to geographical areas and distinguished between 'eastern' and 'western' nationalisms. For Kohn, the dividing line between eastern and western nationalisms was the river Rhine. To the east of the Rhine, an organic, deterministic variety of nationalism developed in clear contrast to the western rational and voluntaristic variety. In a similar vein, Plamenatz argued that nationalism of the eastern kind was 'illiberal', 'backward', 'imitative' and 'competitive' while the western variety was 'culturally better equipped' for 'success and excellence' (Plamenatz, 1976). The works of Meinecke, Kohn and Plamenatz paved the way for a series of scholarly works that developed further the ethnic-civic divide and set the tone of the academic debate: ethnic nationalism was associated with exclusion, xenophobia and violence; while 'civic nations' were associated with liberal regimes capable of integrating newcomers and providing universal and humanistic values.

More recently, the ethnic-civic divide has been reformulated, regaining its utility as an analytical tool (Brubaker, 1992; Greenfeld, 1992). It is precisely in the changing emphasis on political or cultural factors made by the nationalist discourse where scholars have drawn a line between 'civic' and 'ethnic' nationalism. Anthony Smith, for instance, describes two ideal concepts of nations (Smith, 1994). First, the 'civic' conception considers the nation as a community of destiny defined by a common body of law, which applies to all citizens and is in turn the origin of all legislation. Civic nationalism is also characterized by its will to impose a public culture and a 'civic religion', based on a common language, via mass education. Republican France can be considered the most successful model of civic nation.

Second, nations can also be created out of pre-existing ethnies. Ethnic nationalism emphasizes the distinctive racial, linguistic, religious or cultural factors of the original ethnie and aims to return to its 'Golden Age'. Unlike its 'civic' counterpart, the ethnic nation is not defined in terms of political rights but on cultural principles. The romantic conception of Germany developed by Fichte at the beginning of the 19th-century provides a good example of an ethnic nation.

Finally, it is possible to identify both models of nations within the borders of the same nation state and cultural community. In these instances, a civic model of nation confronts the ethnic version of the same nation. The case of France during the Dreyfus affair, when the liberal-democratic canon openly clashed with the vernacular and clerical model defended by the traditionalists, is a clear illustration of competing models of nations within the same state. Moreover, ethnic and civic elements usually coexist in the same nationalist discourse. As Anthony D. Smith has argued, the different conceptions of the nation are 'closely intertwined' and tend 'to move from one version to another as circumstances dictate' (Smith, 1998).

Contrary to some monolithic views, this article will illustrate that Spanish 
nationalism has not remained static and homogenous throughout its two centuries of existence. ${ }^{3}$ Rather, it has changed and evolved throughout time, incorporating both ethnic and civic elements in the discursive formation/'creation' of the Spanish nation. Two main canons of the Spanish nation can be detected in the 19th-century: liberal and traditionalist. The liberal canon is usually associated with civic nationalism, while the traditionalist is described as ethnic. Nevertheless, it is argued here that throughout the 19th-century these two traditions coexisted and were constantly re-elaborated, emphasizing ethnic and civic features and diverse alternatives for the state territorial organization, as political circumstances dictated. This changing character of Spanish nationalism in the last century can be better understood following a 'double dialectic of confrontation' at the discursive level. On the one hand, we analyse the interaction in the creation and development of the opposed concepts of Spain defended by liberals and traditionalists. On the other hand, the confrontational dialogue that both liberals and traditionalists maintained with the peripheral nationalisms of Catalonia and the Basque Country forced the former to reshape their own definition of the 'fatherland', showing the ethnic-civic fluctuation in the nature of Spanish nationalism.

\section{THE CREATION OF THE MODERN NATION, 1808-98}

In Spain, the co-existence of a 'civic' and an 'ethnic' concept of the nation can be traced back to the first decades of the 19th-century, when the liberal and the traditionalist models of Spain were first formulated (Fox, 1997).

The modern liberal concept of Spain was created during the Peninsular War (1808-14). The invasion of Napoleonic troops mobilized an important sector of the population in the struggle against the French and triggered the liberal revolution, which resulted in the approval of the first Spanish constitutional text. In March 1812 the National Assembly, Cortes Generales, passed a Constitution which established the 'Spanish nation' as the utter sovereign, and recognized Spain as a national, constitutional, parliamentarian and Catholic body. If the 1812 Constitution gave legal shape to the liberal concept of the Spanish nation, wartime also showed the 'invention of traditions' to justify abandoning the absolutist regime. Liberals recreated a medieval popular inheritance in order to define the national community in terms of a common history and culture (Riquer, 1994). Thus Aragon's medieval parliaments and the Castilian Comuneros' opposition to Habsburg rule were highlighted as historical episodes which illustrated the pre-modern origins of Spanish liberalism. In turn, this new celebration of 'popular' and 'democratic' institutions justified the liberal political view, which held that new participatory bodies be created within a modern state. 
In other words, the liberal idea of Spain was essentially civic but since the very beginning it also incorporated an important ethnic perception of the nation as a community shaped by history and culture (Núñez, 1999).

During the Isabeline era (1833-68) moderate liberals in power elaborated a nationalist mythology following the canons established in Cádiz. The fight against the French was then named the 'War of Independence' and became the pillar of national myth making. Hundreds of monuments were erected to commemorate the struggle's martyrs and the 2nd of May was converted into a national holiday. Moreover, the 'people' became the main character in literature and academic books, which underlined the historical continuity of the Spanish Volkgeist (Jover, 1984). The practical goal of this production of general histories of Spain was to legitimize the construction of the liberal state and contemporary bourgeois social values. The underlying idea was that from history one could grasp the 'nation's spirit', as the result of its unique history, culture and geography 'from which derived a set of moral prescriptions for individual and collective life' (Álvarez, 1996). At the political level, moderate discourse defended a uniform centralized state as the best way to cement the liberal order, while maintaining an ethnic identification between Catholicism and Spanish national identity.

A more civic alternative to the moderate canon of Spain came from progressive liberals and republicans. They interpreted the medieval Cortes, fueros (local rights) and religious tolerance as the hallmarks of the Spanish nation's Golden Age. Conversely, Habsburg rule, 'foreign' absolutism, and religious intolerance had paved the way for Spanish decadence. Finally, freedom, democracy, and, in some versions, republicanism were the redemptive ideals of the liberal-progressive model (Álvarez, 1996). Unlike the moderates, progressive liberals supported the construction of a decentralized state. They justified this political position by idealizing the medieval local statutes and municipalities, as the 'historical protectors' of so-called 'regional freedoms' (Núñez, 1999). Consequently, when advocating a decentralized state, democrats also claimed to be preserving the 'traditional' political structure of the nation. But ideological intentions and political realities proved difficult to marry. When progressive liberals were in power (1868-74) the political system remained highly unstable and the federal experience during the First Republic (1873-74) could never be properly developed.

The conservative-traditionalist canon of Spain is the concept of nation competing with liberal thought. It also has its early formulation in the 'War of Independence', when defenders of the Ancien Régime defined the Spanish nation as intrinsically Catholic and mobilized the population to fight the 'atheist invader'. Absolutists, and latterly Carlists, considered liberal ideas 'anti-Spanish' and against the country's 'traditions'. These alleged 'traditions' were in fact a modern invention of the reactionary forces, copied from the traditionalist discourse elaborated in France during 
the Revolution, but the anti-liberal rhetoric was widely used as an ideological tool to defend the privileges of the Church and the Crown (Herrero, 1973). It was not, however, until the second half of the 19th-century that reactionary thinkers realized the potent appeal of nationalism, and the traditionalist version of the patria was fully elaborated by Catholic historians such as Marcelino Menéndez Pelayo. In this model, Catholic unity was the common denominator of the foundation of Spanish nationality, which legitimized the monarchy as the national political institution par excellence. Traditionalist historians explained the pinnacle of Spanish power in the 16th- and 17th-centuries as a consequence of the struggle against 'foreign heresy' in Europe and the evangelization of the Americas. They also blamed French rationalism for the artificial introduction of revolutionary ideas that supposedly destroyed the unity of Spanish culture. Contrary to the liberal-progressive model, traditionalists found the Spanish Golden Age to be in the time of the first Habsburgs and blamed Bourbon reformism for the nation's decadence. Their redemptive ideal was a community politically and religiously united, led by a strong Crown and an independent Catholic Church.

This traditionalist concept was essentially ethnic. It emphasized a common religious culture as the Volkgeist of the nation and left virtually no space for 'civic' political rights. Needless to say, this theocratic and romantic conception of the nation was adopted by all those traditionalist groups opposed to the liberal state, such as the Carlists, the Catholic integrists, and significant sectors of the Catholic hierarchy (Álvarez, 2001). Concerning the state structure, the traditionalists advocated a decentralized Spain, where regions would maintain their medieval privileges. The restoration of the Ancien Régime would thus entail the reinstatement of old territorial charts and statutes. This in turn would signal a return to the nation's Golden Era (Núñez, 1999). In opposition to liberal centralization and throughout the 19th-century, the defence of the fueros increasingly became a propaganda tool to mobilize support for the traditionalist cause, gaining significant success in the rural areas of Navarre, the Basque Country, and Catalonia.

During the Restoration (1874-1923), the right wing of the Conservative party defended a very similar ethnic pattern of the Spanish nation, within the liberal monarchic system. Antonio Cánovas, architect of the Restoration system and Conservative leader, conceived of nations as biological organisms with their own 'national character' shaped through the centuries by tradition and culture. This historicist-romantic conception did not completely rule out the liberal idea of a shared will and communal consciousness in the formation of nations, but it certainly gave more importance to divine determination. Beyond all geographical, cultural, racial and linguistic aspects, nations were 'God's acts', declared Cánovas in 1882 (Vilar, 1984). Unlike the traditionalists, however, these sectors of the 
right were strongly unitarian. Following the moderate-liberals' route, they bid for the end of medieval regional privileges and attempted to unify legislation and centralize the state administration during the last quarter of the century.

Throughout the 19th-century these two versions of Spanish nationalism - the liberal and the traditionalist - framed their discourses, incorporating both civic and ethnic features. They were also divided into different groups, not so much due to a conflicting concept of the nation but because of the territorial state framework they advocated. Liberals certainly emphasized civic over ethnic characters in their 'construction' of the patria, but the split between federalists and centralists shows that two different views on state structure can emerge out of a similar perception of the nation. The traditionalist version stressed one cultural factor, Catholicism, as the essence of the Spanish Volksgeist, and yet the political factor of the monarchy as the institution that had historically 'created' the political community remained. Again, the main differences between traditionalist branches responded to the territorial organization of the state, fluctuating between Carlist regionalism and conservative centralization.

\section{SPANISH NATIONALISMS VS. PERIPHERAL NATIONALISMS, 1898-1975}

During the 20th-century, Spanish nationalism continued to fluctuate between liberal and traditionalist conceptions of the nation. This time, however, the two traditions gradually galvanized the state into becoming a counter-force against peripheral nationalist parties (Pozo Andrés and Braster, 1999).

By 1898, the nationalisms of the Basque Country and Catalonia had emerged as alternative sources of national identity and threatened the hegemonic position of Spanish nationalism. Three main factors explain the emergence of Basque and Catalan nationalisms at the turn of the 20thcentury. First, the fraudulent political system established by the Restoration (1875-1923) in which the Liberal and Conservative parties took office in turns, alienated large sectors of Spanish society. In an age of mass politics in which Spain was becoming a modern nation, the Restoration was an inadequate system to express new political concerns. Second, the process of rapid industrialization in Catalonia and the Basque Country in the last decades of the 19th-century led to profound socioeconomic transformations, with a significant flow of Castilian immigrants into these regions and the subsequent ethnicist reaction of the local lower middle classes who considered their 'traditional' way of life under threat. Third, after the 1898 'disaster', Spain not only lost its colonies (Cuba, Puerto Rico and the 
Philippines) but the opportunity to engage the masses in the imperial project - following the pattern established by the United Kingdom, France, and Germany. Hence, the rise of Basque and Catalan political nationalisms, which had been preceded by periods of cultural revival, can be seen as a reaction to the Restoration system and the failure of Spanish elites to incorporate all sectors of society into the national ideal (Corcuera, 2001; Riquer, 1994; Ucelay, 1995).

Parallel to the emergence of peripheral nationalisms, liberal intellectuals proposed the 'regeneration' of Spain. The idea of national regeneration was certainly not invented at the turn of the century, but during the 1890s and especially after the military defeat in Cuba and the Philippines, cultural elites steadily propagated the need for a national rebirth. During the 25 years that followed the loss of the empire, the so-called Generation of 1898, which included figures such as Miguel de Unamuno and Joaquín Costa, and later the Generation of 1914, led by the philosopher José Ortega y Gasset, sought to identify the essence of the Spanish national character. Their goal was to explain contemporary reality through an understanding of the national character and ultimately provide practical solutions for Spanish regeneration.

Despite the diversity of analyses and conclusions, it is possible to discern some common traits in the regenerationist discourse. First, it conceived of the nation as an organic whole that had to be understood as an evolutionary progress. This view combined romantic German historicism and new currents of vitalism, but it was also steeped in Social Darwinist postulates and geographical determinism, so much in vogue in fin-de-siècle Europe. Second, it highlighted the centrality of Castile in the historical formation of the nation in the Middle Ages and Castilian as the national language; and yet advocated the regeneration of the municipalities and local life as the starting point of national reconstruction. On the one hand, these postulates challenged the Restoration centralist system, which was considered inefficient and guilty of destroying the 'popular national life' (Fox, 1997). On the other hand, regenerationists criticized the emerging Catalan and Basque nationalism as artificial, bourgeois, and backward looking. They denounced the peripheral middle classes for turning to regionalist and nationalist movements, labelling them selfish and reactionary, but usually held the oligarchic system of the Restoration ultimately responsible for the emergence of the 'separatist' ideas (Storm, 2000). In doing so, the regenerationists significantly contributed to the growth of a new Spanish nationalism, as well as to the nascent dialectic between Spanish and peripheral nationalism that dominated the 20th-century.

This was a nationalism that sought to modernize Spain via industrialization, social reform and democratization. The 'Europeanization' of Spain became the main aim: the country had to open itself to modern trends and catch up with western nations. This transformation, however, had to be 
undertaken in perfect harmony with the geographical peculiarities of Spain and, above all, with the spiritual character and psychology of the people. This illustrates a twofold tendency in which the desire of modernization was combined with the need to deepen the nation's past to find the 'popular spirit' that had survived through the centuries (Serrano, 1998). Regenerationism was a civic nationalism in which the idea of a community unified by a common democratic law remained essential. Yet it differed from the previous liberal-progressive nationalism in its deep historicism and vitalism, which signalled the overcoming of positivist tendencies that had dominated the thought of 19th-century democrats.

The first decades of the 20th-century also witnessed a profound evolution of the conservative-traditionalist canon of Spain, which incorporated Castilian language, previously a liberal feature of Spanishness, into its ideological repertoire. In fact, the development of peripheral nationalism produced a reaction from different right-wing groups which favoured the emergence of a new authoritarian, anti-liberal, Catholic, and centralist Spanish nationalism. One of the key social groups in the re-elaboration of the conservative canon of Spain were professional army officers, who developed a new military nationalism combining regenerationist tenets with traditional Spanish nationalism and who advocated an authoritarian state as a means to modernize the country (Balfour, 1996). This new authoritarian canon of Spain became official in September 1923, when the Captain General of Catalonia, Miguel Primo de Rivera, ousted the liberal regime via military coup, invoking the 'separatist threat', the inefficient parliamentary system, and the actions of organized labour. With the support of the King, radical sectors of the Conservative Party, the Church, and the army, the primorriveristas postulated a monarchist ultra-Catholic idea of the nation, in which religion, the Castilian language, and the common imperial past represented essences of the Spanish people. Following authoritarian currents rising at the time in Europe, particularly fascism, Primo and his ideologues attempted to build a new corporatist and centralist state, which could integrate social classes and regional identities under the authoritarian national ideal, later known during Francoism as NationalCatholicism (Quiroga, 2000).

The primorriverista ethnicist drive sought to combat the rise of peripheral nationalisms with pro-Castilian linguistic policies, in an attempt to deprive peripheral nationalists of their cultural appeal among Basque and Catalan speakers. However, government repression did not bring about the desired effect. Indeed, it led to the reinforcement of peripheral nationalist tendencies in the 1920s. In the Basque Country, a fragmented nationalist community withdrew from the political scene and devoted its efforts to 'cultural regeneration' in anticipation of a political opportunity. With the fall of Primo de Rivera in 1930, the two existing parties fused into the Partido Nacionalista Vasco (PNV) and Basque nationalism ceased to 
appear as radical and romantic as in its early years. Many in the middle classes began to see Basque nationalism as the most effective means of defending their interests and 'way of life'. In Catalonia, different nationalist factions also came together in their struggle against the dictatorship, and cultural production in the Catalan language increased, while democratic republican Catalan tendencies gained mass support (Granja et al., 2001). More importantly, after the fall of the dictator, Spanish liberals, republicans, and socialists reached a political agreement with peripheral nationalists to establish a secular, democratic and decentralized republic. The failure of the more authoritarian Spanish nationalism in dealing with peripheral nationalism paved the way for a non-centralist re-evaluation of the liberal-democratic version of Spain.

With the advent of the Second Republic in 1931, Spanish liberals and socialists tried to find a solution to the regionalist question through measures of state decentralization. The views of liberal and republican intellectuals, such as José Ortega y Gasset and Manuel Azaña, dominated political discourse on the subject. This was an essentially civic discourse, which identified the Spanish people as a democratic political community defined by a common body of law. Yet a certain cultural determinism can also be detected in the republicans' idea of the patria, for Spanish unity was understood in historical, linguistic, and cultural terms. Nevertheless, republicans and socialists acknowledged the existence of particular cultures and contemplated home-rule statutes for those areas where nationalist sentiments were strong, seeking their accommodation within the structure of the Spanish state. Hence the 1931 Constitution proposed the creation of an 'integral' state, an alternative framework that maintained the Spanish people as the sole national sovereign, while allowing the creation of homerule statutes in certain regions. Catalonia obtained her home-rule statute in 1932 and the Basque Country in October 1936. It was too late. On July 18 that year, a military rebellion against the Republic led to the Spanish Civil War (1936-39) and the Basque statute was never fully developed.

The Civil War was not a fight between Spanish nationalism and peripheral nationalism, but there are few doubts that the military rebels saw the development of home-rule statutes as a direct threat to the unity of the fatherland. During Franco's dictatorship (1939-75), the 'conservativetraditionalist' version of Spanish nationalism became dominant in the shape of National Catholicism, an ideological blend of fascist, Carlist, neotraditionalist and military principles (Saz, 2003). After his victory in the war, Franco imposed a military, proto-fascist, and ultramontane canon of Spain, representing Catholicism as the essence of Spain, and emphasizing Castile as the 'ethnic core' of the nation. Consonant with its totalitarian aspirations, Franco's regime systematically repressed those political opponents who challenged National Catholicism. The Basque and Catalan home-rule statutes were abolished and a new state was built on legal, 
administrative, and territorial centralism. Moreover, the dictatorship steadily applied policies of cultural assimilation: Spanish was declared the only official language, and particular signs of regional identities (e.g. languages, flags, and anthems) were banned and persecuted.

Franco's ethnic concept of the nation went hand in hand with the idea of national regeneration. Not only did the Francoist propaganda rewrite the Civil War as a 'crusade', it re-elaborated the image of the 'anti-Spain', a mythological figure which incorporated liberals, republicans, leftists, and peripheral nationalists - all portrayed as the 'cancer' of the nation. According to the regime's ideologues, that 'disease' had to be 'cured' by 'creative and purifying' violence (Richards, 1998). However, the regime's dependency on violence provoked a violent reaction from a new generation of nationalists. In 1959, ETA (Euskadi ta Askatasuna; Basque Country and Freedom) started its war of 'national liberation' against Spain. ETA's ideology was a mixture of radical Basque nationalism and Marxist rhetoric, which borrowed elements of Third World liberation movements. ETA's violent confrontation led to fierce repression from the Francoist regime, which, in turn, invigorated popular Basque consciousness in what came to be known as the action-repression-action spiral, and served as a unifying factor not only among Basque nationalists, but also Spanish leftists, democrats and Catalan nationalists (Jáuregui 1986). The Catalan opposition to Francoism was radically different to that in the Basque Country. During the 1960s and early 1970s, political opposition to the dictatorship was accompanied by a cultural revival in literature, art, and music, which fostered Catalan national identity. Furthermore, Catalan nationalists joined forces with communists, socialists and liberals to fight against the dictatorship, much in the same manner they had done before the proclamation of the Second Republic.

Thus the same historical pattern as at the beginning of the 20th-century is to be observed in the period of the Second Republic and Francoism. The political achievements of peripheral nationalisms brought a dictatorial reaction from Spanish conservative nationalism, which attempted to suppress Catalan and Basque nationalism through political and cultural repression. This repression, in turn, fostered peripheral nationalisms, which gained broader popular support, allied with the Spanish left and liberals in their opposition against the dictatorship. By the death of Franco in 1975, the idea of a democratic Spain had become associated, once again, with decentralization and home rule for Catalonia and the Basque Country.

To sum up, in the period 1898-1975 two different discourses of Spanish nationalism, 'liberal-democratic' and 'Catholic-traditionalist', became discursive backbones of different political systems. Firstly, liberaldemocratic Spanish nationalism was briefly exercised during the Second Republic and aimed at integrating, rather than excluding, the different nations through institutional reforms such as devolution. Second, the 
'Catholic-traditionalist' form of nationalism was implemented during the dictatorships of Primo de Rivera and Franco. These regimes were characterized by their defence of an ethnic concept of Spain (religious and linguistic) and their centralist and authoritarian policies. Attempts to suppress peripheral nationalisms through political and cultural repression, however, had a contrary effect to that pursued. The denial of Basque and Catalan national identities actually fostered peripheral nationalism, which gained broader popular support.

\section{DEMOCRACY AND THE REFORMULATION OF THE DIALECTIC, 1975-2004}

During the Spanish transition to democracy (1975-78), there was an upsurge in support for political autonomy in Catalonia and the Basque Country, as a reaction to the authoritarian Spanish nationalism imposed during the previous four decades. Unlike the 1930s, however, demands for regional autonomy did not limit themselves to Catalonia, the Basque Country, and, to a lesser extent, Galicia, but spread all across Spain. Regions like Andalusia, Aragon, Valencia, Asturias, or the Canary Islands expressed diverse levels of regional identity and claimed their own political power within a decentralized state. This generalization of regional political demands shows the degree to which the idea of a democratic Spain had been associated with decentralization to the discredit of National Catholicism. From 1976 onwards it seemed clear that the state would have to rest on two pillars: parliamentary democracy and regional autonomy (Clark and Haltzel, 1987).

The 1978 Constitution was a compromise between very diverse political forces attempting to find a political solution to the national question in Spain. The Constitution sought to reconcile the centre-periphery tension throughout the text. Article 2 advocated 'the indissoluble unity of the Spanish nation' while it also recognized and guaranteed 'the right to autonomy of the nationalities and regions of which it is composed'. Regarding language, Castilian was declared the 'official language of the state', but 'other Spanish languages shall be official in their respective Autonomous Communities' (Article 3.). The word 'nation' was, however, reserved for the Spanish as a whole while Catalonia, the Basque Country and Galicia were considered 'historic nationalities'. Under the new arrangement, Catalonia, the Basque Country and Galicia obtained their own statutes of autonomy and, throughout the 1980s, the example was followed by all regions in Spain, bringing the number of autonomous communities up to 17 .

The 1978 Constitution differed from that of 1931 in that the latter mainly 
dealt with Catalan nationalism and did not attempt a deep transformation of the state's territorial structure. The 1978 text, by contrast, dealt with Catalan, Basque and Galician ethnonational differences, while attempting to restructure Spain as a quasi-federal state. A State of Autonomies (Estado de las Autonomías), replaced the centralized structure of the state. The Constitution, and its continuation in the 1981 Law of Autonomic Harmonization (LOAPA), allowed all regions to have their own parliament and decision-making process. As a result of the implementation of the autonomic model, and the concomitant establishment of political and cultural bodies devoted to fostering regional distinctiveness, national and regional identities tend to overlap in most of the population. Nowadays, up to 50 percent of Spaniards identify themselves equally with their region and Spain while only 26 percent consider either the region or Spain more important than the other (Moral, 1998).

Spanish nationalists' reaction to the new constitutional settlement was mixed. While the vast majority of political parties participated in the drafting of the new Magna Carta, a minority of die-hard Francoists opposed it and used the army to reinstate the National Catholic canon of Spain. The 1981 military coup d'etat was the last attempt to restore a centralist and authoritarian regime, and its failure signalled the end of National Catholicism as a political option. Although the immediate cause that triggered the coup was ETA's political violence, which frequently targeted army and police officers, further reasons behind the military coup were the alleged dangers democracy and devolution posed for the unity of the fatherland. Yet the military coup backfired. It not only led to the consolidation of the democratic regime and stabilized territorial decentralization, it also completely cleared the electoral landscape of extreme right parties. After the coup, the conservative Prime Minister, Leopoldo Calvo Sotelo, and the leader of the socialist opposition, Felipe González, reached an agreement to rationalize and advance the process of devolution, in an attempt to conciliate regional demands and strengthen the new constitutional system.

Despite these threats to Spanish democracy, the constitutional order was consolidated during the early 1980s. The Socialist party, in power from 1982 to 1996, promoted a discourse of state modernization as a means to reinforce democracy, which intentionally downplayed references to the Spanish nation. This discourse rested on two main pillars: the creation of a decentralized state and the integration of Spain into the European Economic Community (EEC). Regarding the former, the progressive implementation of the statutes of autonomy showed the viability of a decentralized state. Additionally, the entrance of Spain into the EEC in 1986 became the hallmark of the Spanish left's Europeanist 'vocation' and the acknowledgment of the country's transformation since 1975. Spain was no longer regarded as a backward-looking and authoritarian state but as a modern, secular and European democracy. 
In a sense, Spain's inclusion in the process of European integration has to be seen as the culmination of a long project of Europeanization of a country defended by liberal and democratic Spanish nationalists ever since the crisis of 1898. During the 1980s and 1990s, both socialists and communists slowly 'rediscovered' the historical legacy of the Spanish 'civic' nationalism in the figures of intellectuals and politicians like Ortega y Gasset and Azaña. Although the approaches to the territorial organization of the state ranged from federalism to the improvement of the current State of the Autonomies, the left continually emphasized the idea of solidarity among the regions and defended its loyalty to the 1978 Constitution as main elements of its discourse. From this perspective, Spain was a 'nation of nations' in which different cultures and languages could live together under the same Constitution (Núñez, 1999).

Following a very different political transformation, the Spanish right also ended up defending a similar national pattern during the 1990s. The Spanish conservative party (Partido Popular, PP), which had inherited the Francoist tradition of Alianza Popular (AP), reformed itself to present a moderate programme of liberal Spanish nationalism. From its initial opposition to the development of statutes of autonomy in the early 1980s, the conservative party changed to full acceptance of the 1978 Constitution as the only possible political framework for Spain. The right also partially set aside its providential view of the nation inherited from National Catholicism, recovered the intellectual heritage of the regenerationists of the first third of the 20th-century, and presented Spain as a modern European and multicultural nation. This view defined Spain as the only nation in the Spanish state and established a dialectical struggle with peripheral nationalists, who conceived Spain as a mere state and Catalonia and the Basque Country as the real nations integrated in it (Vidal, 1997).

Therefore, nowadays it is possible to detect, both in the right and the left, a renovated Spanish nationalism, which has retaken the legacy of early 20th-century liberal-democratic nationalism and describes itself as modern, civic, plural, and European, challenging the 'ethnic' peripheral nationalisms of Catalonia and the Basque Country. Rhetorically, this new nationalism heavily relies on Jürgen Habermas' concept of 'constitutional patriotism', which defends the idea of citizenship-based universal civic principles rather than a shared culture. For Spanish constitutional patriots, Spain is a multicultural nation politically bounded by a 'democratic contract', as established by the 1978 Constitution. And it is loyalty to this legal text that guarantees the necessary civic consensus among Spaniards. ${ }^{4}$ This new Spanish nationalism has endowed itself with certain symbols and policies attached to its idea of the Spanish nation. The concept of the Crown as the historical unifying element in the history of Spain, the defence of the Castilian language in Catalonia and the Basque Country (where Castilian 
is seen to be increasingly marginalized), and the attempt to establish a common interregional curriculum in history and social sciences for the whole of Spain, are just some examples of these manifestations of Spanish nationalism. A special mention should be made here of King Juan Carlos I, who has become a symbol of democracy since he publicly defended the constitutional order against the military coup in 1981. The monarchy is today the most respected institution and critiques of the King are almost non-existent. ${ }^{5}$ Nevertheless, the factor that most contributed to the consolidation of this 'civic nationalism' during the 1990s has been ETA's political violence. Since Francoism, the Basque armed group has hardly evolved in its political discourse (which holds that the Basques are an oppressed nation and need to resort to violence to liberate themselves) and has increasingly used terrorist tactics. The reaction from Basque and Spanish civil society against terrorism has reinforced Spanish national identity as democratic, presenting ETA as Spain's main problem. ${ }^{6}$ Spanish conservatives and socialists have sought to channel this social contempt for political violence. For example, the anti-terrorist pact signed by PP and Partido Socialista Obrero Español (PSOE) in December 2000 emphasized the 1978 Constitution and the Basque Statute of Autonomy as the political framework in which the terrorist question had to be solved, and presented ETA as the greatest enemy of Spanish democracy.

For all the exclusively civic character this new Spanish nationalism claims, the record suggests that some ethnic elements lie underneath the constitutional patriots' version of Spain. The need to present Spain as a unique historical and cultural community, endorsing the political community, remains a foundation on which to justify the existence of the Spanish nation well before the 1978 Constitution. The key here is to be found in the Constitutional patriots' rediscovery of early 20th-century Spanish nationalists, most specifically the figure of José Ortega y Gasset. Ortega's liberal idea of Spain was never detached from a certain historical determinism, ultimately portraying the Spanish nation as the product of History (Bastida, 1997). Although often concealed or implicit, the same historical determinism can be detected in the moderate leftists' concept of Spain. In their eyes, Spain is a 'nation of nations', but, within this plurality, there is a single sovereignty and a collective project for the whole community, whose existence is legitimized by a common history. As Xosé M. Núñez Seixas has pointed out, this necessity to appeal to a common and pre-constitutional past indicates the impossibility of creating a pure civic patriotism, exclusively based on loyalty to the constitutional text and completely devoid of historical and cultural elements (Núñez, 2001).

Cultural and historical endorsement of the civic idea of Spain has been even blunter in the conservative political discourse. While defending a multicultural Spain, the creation of the nation was dated to the 15th-century, when the marriage of Isabella of Castile and Ferdinand of Aragon 
assembled both crowns, and common historical enterprises such as the colonization of the Americas endowed the Spanish peoples with a shared past on which future common enterprises could be based (Aznar, 1995). Some of the policies implemented by the conservative PP government have shown the implications behind this concept of nation. Special attention was paid to the promotion of Castilian language in schools, particularly in Catalonia and the Basque Country where regional governments' linguistic policies of 'Catalanization' and 'Basquization' were regarded as an attack on Spanish speakers. The teaching of history also became part of the political battleground. By incorporating common topics of Spanish history into the syllabus, the central government reforms of the history curriculum sought to prevent the so-called 'regional atomization' of the teaching of history (Pérez et al., 2000).

Moreover, the right slowly revived the religious element as a component of Spanish national identity. In 1997, for instance, the state-funded Royal Academy of History published a collective book, which defended a primordialist vision of Spain and presented Christianity at the core of the nation's historical formation (Benito, 1997). PP proposals for imposing Catholic religion as a compulsory subject in public schools' curriculum, and increasing state funding of private religious schools, properly exemplified the growing conservative trend of emphasizing Catholicism as a component of national identity. The conservative central government's immigration policies also displayed a certain 'ethnic concern' based on their idea of Spain. The PP government authorized the entrance of one million Latin American immigrants due to an economic necessity for cheap labour. Religious and linguistic affinity prevailed here over the more immediate choice, however, which would have been North African workers, a community considered more difficult to assimilate than Spanish speaking Americans. ${ }^{7}$

It is therefore evident that constitutional patriotism is a neo-Spanish nationalism essentially, but not completely, civic. Cultural features remain important in both discourse and policies, ranging from historical determinism to the recovery of ethnic factors, such as language and religion. Furthermore, although socialists and conservatives have reached an effective consensus in the defence of the Constitution and the statutes of autonomy, as a result of their dialectic confrontation with peripheral nationalists willing to modify the constitutional framework, the old divisions between the two models of Spanish nationalism re-emerge in times of political crisis. For example, in March 2003, when the conservative government was facing a vast social mobilization against the war in Iraq, PP leaders resumed the pre-civil war discourse of the existence of two antagonist Spains and accused socialists, communists and peripheral nationalists of being 'anti-Spanish', much in the same manner as the authoritarian right did throughout the 20th-century. ${ }^{8}$ 


\section{CONCLUSION}

This article has shown that a pervasive feature of Spanish nationalisms in the last two centuries has been the combination of ethnic and civic components in the concept of nation. Moreover, the emphasis on ethnic or civil features in Spanish nationalist discourses has changed depending on political circumstances. The conservative canon has tended to highlight ethnic elements and liberal nationalism has emphasized civic factors. Yet no model of Spanish nationalism has historically been either purely ethnic or civic. The need to justify the existence of a political community based on a common history has forced civic nationalism to incorporate cultural elements into its discourse. At the same time, the requirement of granting the cultural community a political form makes the incorporation of certain civic features unavoidable for ethnic nationalism. During the 19th-century, the evolving nature of Spanish national identity can be understood following the different liberal and traditionalist's conceptions of Spain, in terms of both the ethnic-civic divide and their proposals for state territorial organization. The emergence of peripheral nationalist movements at the turn of the 20th-century introduced a new variant into the Spanish nationalist discourse that led to further changes in the concept of the Spanish nation. The conservative canon went through a process of further ethnicization, adopting previously liberal features such as the promotion of the Castilian language, and radicalizing Catholic bigotry as hallmarks of national identity. The liberal idea of Spain, in turn, increasingly adopted a democratic and multicultural nature, in an historical process that had much to do with the opposition to the National Catholic canon and the political alliances progressive forces reached with peripheral nationalists during authoritarian periods.

The 1978 constitutional arrangement has led to an increasing consensus on the democratic nature of the Spanish nation and the decentralized structure of the state. The changing nature of modern Spanish nationalism can be seen in its acceptance of the different cultural and national groups within Spain and in its self-portrayal as an example of 'civic' nationalism - in clear opposition to the 'ethnic' peripheral nationalisms. Yet this does not signal the end of the dialectic Spanish nationalism versus peripheral nationalisms, let alone the disappearance of Spanish nationalism. As we have seen, this new nationalism is not entirely civic and incorporates historical determinism and cultural features in its definition of Spain.

New challenges in the 21st-century, already latent during the 1990s, are likely to change further the political discourse of both Spanish and peripheral nationalists and therefore to reformulate the very nature of their relationship. The new role of the nation state, the transformation of the European Union, Islamic fundamentalism and, above all, the impact of 
non-European immigration in Spain, are contemporary issues that will lead to the further reshaping of national identities in the Iberian Peninsula. Whether this transformation of national identities will take an ethnic or civic line is difficult to determine.

The supremacy of the civic elements over the ethnic ones in the constitutional patriotic discourse is by no means guaranteed for the future. Further research on this area will have to deal with the epistemological problem of distinguishing between the more communal expressions of Spanishness and the more institutional and associative aspects, together with the changing nature of Spanish nationalism in an increasingly interconnected world. In all cases, both the civic and ethnic trends are likely to remain relevant in the evolving discourse of Spanish nationalism.

\section{Notes}

1 Ortega y Gasset (1999[1914]), pp. 72.

2 A first article, by Juan Pablo Fusi, argued that it was the failure of the Spanish nationalist project to incorporate the peripheral nationalist elites that produced the birth and development of nationalism in various regions in Spain, namely Catalonia, the Basque Country, and Galicia. An opposing view, held by Borja de Riquer, argued that the reason why the Spanish nationalist project did not succeed was that it did not take into account other pre-existing forms of identity. See Borja de Riquer (1990) and Fusi (1990a; 1990b). Prior to the debate between Fusi and De Riquer, scholars had paid little attention to the topic of Spanish nationalism. During the 1980s, the few works on the subject were those of José María Jover Zamora (1984), Paloma Cirujano et al. (1985) and Andrés de Blas Guerrero (1989).

3 For a view of Spanish nationalism as inflexible see Letamendía (2000). For a view in which Spanish nationalism is 'given' see Linz (1973).

4 For the official PP postulates on constitutional patriotism see Pique and San Gil's 'El patriotismo constitucional del siglo XXI', paper presented to the conservative party congress in January 2002.

5 The Spanish Penal Code punishes mocks, calumnies, and injuries against the Crown and the use of the King's image to damage royal prestige (Art. 490 and 491). The media is very careful with the treatment given to the royal family and it is guided by a strong and self-imposed code of conduct.

6 According to an opinion poll conducted by the United Nations in June 2001, terrorism was the main social problem for 67 percent of Spaniards. Immigration was also considered a problematic issue by 21 percent of the population, in sharp contrast with the polls in 1996, which showed only 2 percent of Spaniards worried about immigration. El País, Madrid, 29 June 2001.

7 In the same vein, José María Aznar joined the Vatican and Ireland in demanding a mention to Europe's 'Christian roots' in the preamble of the European Constitution, showing the will to emphasize religious elements when defining political communities and, as in the case of Spain, to draw a cultural and historical line between the Christian and the Muslim worlds.

8 See, for instance, the comments of Jaime Mayor Oreja, in El País, 31 March 2003. 


\section{References}

Álvarez Junco, J. (1996) 'The Nation-Building Process in Nineteenth-Century Spain', in C. Mar-Molinero, and A. Smith (eds) Nationalism and the Nation in the Iberian Peninsula: Competing and Conflicting Identities, pp. 89-106. Oxford: Berg.

Álvarez Junco, J. (2001) Mater Dolorosa: La idea de España en el siglo XIX. Madrid: Taurus.

Anderson, B. (1991) Imagined Communities: Reflection on the Origin and Spread of Nationalism. London: Verso.

Archilés, F. and M. Martí (2001) 'Ethnicity, Region and Nation: Valencian Identity and the Spanish Nation-state', Ethnic and Racial Studies 24(5): 779-97.

Aznar, J.M. (1994) España: La Segunda Transición. Madrid: Espasa Calpe.

Aznar, J.M. (1995) La España en que yo creo. Discursos políticos, 1990-1995. Madrid: Noesis.

Balfour, S. (1996) “"The Lion and the Pig”: Nationalism and National Identity in Fin-de-Siècle Spain', in C. Mar-Molinero, and A. Smith (eds) Nationalism and the Nation in the Iberian Peninsula: Competing and Conflicting Identities, pp. 107-17. Oxford: Berg.

Bastida, X. (1997) 'La Búsqueda del Grial: La Teoría de la Nación en Ortega', Revista de Estudios Políticos 96: 43-76.

Benito Ruano, E., ed. (1997) España Reflexiones sobre el ser de España. Madrid: Real Academia de la Historia.

Blas Guerrero, A. de (1989) Sobre el Nacionalismo Español. Madrid: Centro de Estudios Constitucionales.

Brubaker, R. (1992) Citizenship and Nationhood in France and Germany. Cambridge and London: Harvard University Press.

Cirujano Marín, P., T. Elorriaga Planes and S. Pérez Garzón (1985) Historiografía y Nacionalismo Español (1834-1868). Madrid: Centro de Estudios Históricos.

Clark, R. and M. Haltzel, eds (1987) Spain in the 1980s: The Democratic Transition and a New International Role. Cambridge, MA: Ballinger.

Corcuera, J. (2001) La Patria de los Vascos: Orígenes, Ideología y Organización del Nacionalismo Vasco (1876-1903). Madrid: Taurus.

Fox, I. (1997) La Invención de España. Nacionalismo Liberal e Identidad Nacional. Madrid: Cátedra.

Fusi, J.P. (1990a) 'Revisionismo Crítico e Historia Nacionalista (A propósito de un artículo de Borja de Riquer)', Historia Social 7: 127-34.

Fusi, J.P. (1990b) 'Centre and Periphery 1900-1936: National Integration and Regional Nationalism Reconsidered', in F. Lanon and P. Preston (eds), Élites and Power in Twentieth-Century Spain: Essays in Honour of Sir Raymond Carr, pp. 33-44. Oxford: Clarendon.

Granja, J.L. de la, J. Beramendi and P. Anguera (2001) La España de los Nacionalismos y las autonomías. Madrid: Síntesis.

Greenfeld, L. (1992) Five Roads to Modernity. Cambridge, MA: Harvard University Press.

Herrero, J. (1973) Los Orígenes del Pensamiento Reaccionario. Madrid: Cuadernos para el diálogo.

Jáuregui Bereciartu, G. (1986) 'National Identity and Political Violence in the Basque Country', European Journal of Political Research 14(30): 587-605. 
Jover Zamora, J.M. (1984) 'Caracteres del Nacionalismo Español, 1854-1874', Zona Abierta 31: 1-22.

Kohn, H. (1944) The Idea of Nationalism. New York: Collier Books.

Letamendía, F. (2000) Game of Mirrors: Centre-Periphery National Conflicts. Aldershot: Ashgate.

Linz, J.J. (1973) 'Early State-Building and Late Peripheral Nationalisms against the State: The Case of Spain', in Samuel N. Eisenstadt and Stein Rokkan (eds) Building States and Nations: Analyses by Region, Vol II, pp. 32-116. London: Sage.

Meinecke, F. (1970[1907]) Cosmopolitanism and the National State. Princeton, NJ: Princeton University Press.

Moral, F. (1998) Identidad Regional y Nacionalismo en el Estado de las Autonomías. Madrid: Centro de Investigaciones Sociológicas.

Núñez Seixas, X.M. (1999) Los Nacionalismos en la España (siglos XIX y XX). Barcelona: Hipótesis.

Núñez Seixas, X.M. (2001) 'What is Spanish Nationalism Today? From Legitimacy Crisis to Unfulfilled Renovation (1975-2000)', Ethnic and Racial Studies 24(5): 719-52.

Ortega y Gasset, J. (1999[1914]) Meditaciones del Quijote, Madrid: Alianza Editorial.

Pérez Garzón, S. et al. (2000) La Gestión de la Memoria: La Historia de España al Servicio del Poder. Barcelona: Crítica.

Piqué, J. and M. San Gil (2002) 'El Patriotismo Constitucional del siglo XXI', paper presented to the 14th PP National Congress, Madrid, January [http://www.pp.es].

Plamenatz, J. (1976) 'Two types of Nationalism' in Eugene Kamenka (ed.) Nationalism: The Nature and Evolution of an Idea, pp. 22-37. Canberra: Australian National University Press.

Pozo Andrés, M.M. del and J. Braster (1999) 'The Rebirth of the "Spanish Race": The State, Nationalism, and Education in Spain, 1875-1931', European History Quarterly 29(1): 75-108.

Quiroga Fernández de Soto, A. (2000) 'La Idea de España en los Ideólogos de la Dictadura de Primo de Rivera. El Discurso Católico-Fascista de José Pemartín', Revista de Estudios Políticos 108: 197-224.

Richards, M. (1998) A Time of Silence: Civil War and the Culture of Repression in Franco's Spain, 1936-1945. Cambridge: Cambridge University Press.

Riquer I Permanyer, B. de (1990) 'Sobre el Lugar de los Nacionalismos-Regionalismos en la Historia Contemporánea Española', Historia Social 7: 105-26.

Riquer I Permanyer, B. de (1994) 'Aproximació al Nacionalisme Espanyol Contemporani', in P. Anguera, J. Beramendi, C. Forcadell, M. González, C. Almuña, R. Blasco, J.L. de la Granja and B. de Riquer, IIIes Jornades de debat. Orígens $i$ formació dels nacionalismes a Espanya, pp. 245-61. Reus: Centre de Lectura.

Saz, I. (2003) España Contra España: Los Nacionalismos Franquistas. Madrid: Marcial Pons.

Segarra I Estarelles, J.R. (2001) 'Imaginar la región y naturalizar la nación: La obra de Vicente Foix', in J.R. Segarra i Estarelles Ciudadanía y nación en el mundo hispano contemporáneo, pp. 139-62. Vitoria-Gasteiz: Instituto Universitario de Historia Social Valentín de Foronda.

Serrano, C. (1998) 'Conciencia de la Crisis, Conciencias en Crisis', in J. Pan-Montojo (ed.), Más se Perdió en Cuba. España, 1898 y la Crisis de Fin de Siglo, pp. 335-403. Madrid: Alianza. 
Serrano, C. (1999) El Nacimiento de Carmen: Símbolos, Mitos y Nación. Madrid: Taurus.

Smith, A.D (1994) 'Tres Conceptos de Nación', Revista de Occidente 161: 7-22.

Smith, A.D. (1998) Nationalism and Modernism. London and New York: Routledge.

Storm, E. (2000) 'El Nacionalismo Español de los Intelectuales: Unamuno, Costa y Ganivet', in R. Sánchez Montero (ed.) En Torno al 98, vol. II, pp. 389-401. Huelva: Universidad de Huelva.

Ucelay da Cal, E. (1995) 'The Nationalisms of the Periphery: Culture and Politics in the Construction of National Identity', in H. Graham and J. Labanyi (ed.) Spanish Cultural Studies: An Introduction, pp. 32-9. Oxford: Oxford University Press.

Vidal Quadras, A. (1997) 'La Nación Translúcida', Política Exterior 11: 131-51.

Vilar, P. (1984) 'Estado, Nación, Patria en España y en Francia, 1870-1914', Estudios de Historia Social 28-29: 7-41.

DIEGO MURO is Lecturer in Spanish and European Politics at King's College London. Address: Department of Spanish \& Spanish American Studies, King's College, Strand, London WC2R 2LS, UK. [email: diego. muro@kcl.ac.uk]

ALEJANDRO QUIROGA is Visiting Lecturer in Spanish History at Royal Holloway University of London. Address: Cánada Blanch Centre for Contemporary Spanish Studies, London School of Economics, Houghton Street, London WC2A 2AE, UK. [email: A.Quiroga@Ise.ac.uk] 